\title{
A SOFT TISSUE INFECTION RESISTANT TO SURGICAL TREATMENT - CASE REPORT
}

\author{
Plachkov I., P. Chernopolsky \\ Second Department of Surgery, University Hospital "St. Marina", \\ Medical university "Prof. Dr. Paraskev Stoyanov" Varna
}

Reviewed by: assoc. prof. V. Ignatov

\section{SUMMARY}

Tuberculosis may affect every organ of human body, but respiratory system is most vulnerable. Rare and exotic localizations of this specific infection are usually an obstacle of thinking about it. We present a case of 44 years old man with infected wound in right gluteus muscle with duration about 6 years, who underwent many surgical interventions in different hospitals.

Key words: tuberculosis, soft tissue infection

\section{INTRODUCTION}

Tuberculosis may affect every organ of human body, but respiratory system is most vulnerable. Rare and exotic localizations of this specific infection are usually an obstacle of thinking about it. Object of these localizations are patients with compromised immunity $(1,2)$.

\section{Case report}

We present a case of 44 years old man with infected wound in right gluteus muscle with duration about 6 years, who underwent many surgical interventions in different hospitals. The patient suffered from spina bifida and lower limbs paresis. Before 6 years he was healed from acute orchitis, recovering after antibiotic treatment.

The wound was with size $10 \times 8 \mathrm{~cm}$, reaching the ischial bone, with thickened walls and purulent secretion. The only abnormal findings in laboratory tests were increased CYE 131 and slight decreased hemoglobin level - $112 \mathrm{~g} / \mathrm{l}$, all others blood indexes were in normal values. The chest $\mathrm{X}$-ray did not reveal any abnormalities. On the pelvis X-ray there was a roughness on the ischial bone outline, just under the abscess cavity. The MRI revealed an inflammation in the same area and reactive changes in the ischial bone.

Under general anesthesia we made an excision of the abscess cavity and curettement of the liable ischial bone to well borders. The pathohistological finding of the soft tissues presentted tuberculosis. A postoperative antibiotic and specific treatment was administered leading to full recovering of the lasting for 6 year soft tissue vice (fig.1).

\footnotetext{
Address for correspondence:

I. Plachkov, Second dept. of surgery, MHAT "Sv.Marina",

Medical university - Varna, BG-9002, Varna,

1, Hristo Smirnenski Str.

e-mail: iplachkov@mail.bg
}

\section{DISCUSSION}

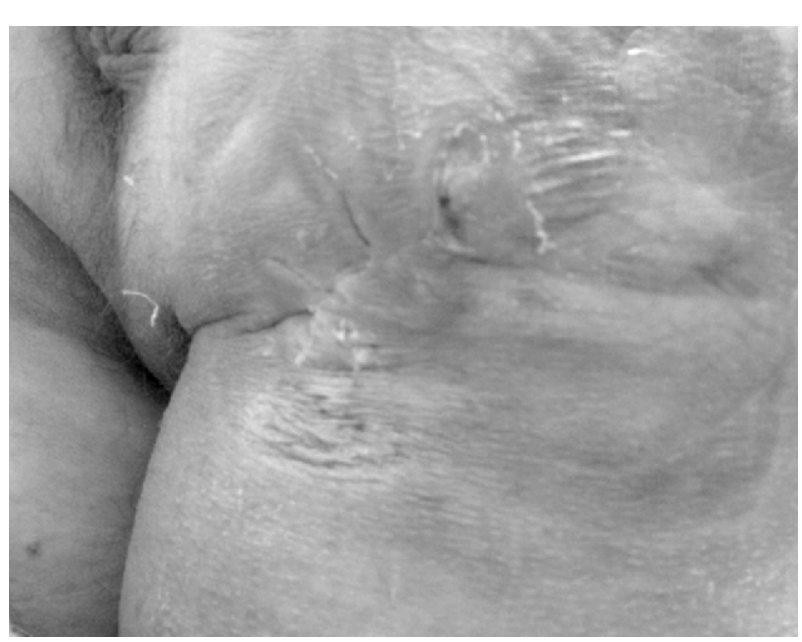

Fig.1

In world literature there are occasional reports for soft tissue tuberculosis, and the largest group of patients with such kind of problem is reported from Stain\&co for the period of 1984-1996 - eleven patients from Canada. An impression is made that almost all the patients are with impaired immunity - after different types of transplantations or immunosuppressive therapy $(4,5)$. In all published cases after a surgical intervention of the lesions was made and specific drug treatment is carried out, the problem was solved in a period from a several months to 2 years (6).

Our clinical behavior is close to the other published cases from different authors. The final result in our case is fully recovering of the local lesion. This allows us to make following conclusions: 
1. We continue of thinking about tuberculosis as a not so rare cause for soft tissue lesions.

2. In patients with similar problem, who carry out immunosuppressive therapy or any other treatment, which leads to impaired immunity is recommended a preliminary tests for proving/rejecting tuberculosis to be made.

3. It is obligatory in these patients a surgical intervention to be done, followed by specific drug treatment.

\section{REFERENCES}

1. Juarez M, Misischia R, Alarcon GS. Infections in systemic connective tissue diseases: systemic lupus erythematosus, scleroderma, and polymyositis/ dermatomyositis. Rheum Dis Clin North Am 2003;29: 163-84.
2. Sayarlioglu M, Inanc M, Kamali S, Cefle A, Karaman O, Gul A, et al. Tuberculosis in Turkish patients with systemic lupus erythematosus: increased frequency of extrapulmonary localization. Lupus 2004;13: 274-8.

3. Feng PH, Tan TH. Tuberculosis in patients with systemic lupuserythematosus. Annals Rheum Dis 1982;41:11-4.

4. Franco-Paredes C, Diaz-Borjon A, Senger MA, Barragan L, Leonard M. The ever-expanding association between rheumatologic diseases and tuberculosis. Am J Med 2006;119:470-7.

5. Puttick MP, Stein HB, Chan RM, Elwood RK, How AR, Reid GD. Soft tissue tuberculosis: a series of 11 cases. J Rheumatol 1995;22:1321-5.

6. Gordon MM, Wilson HE, Duthie FR, Jones $\mathrm{B}$, Field M. When typical is atypical: mycobacterial infections mimicking cutaneous vasculitis. Rheumatology (Oxford) 2002;41:685-90 